\title{
Analysis OfRisk for Class Shifting And Determinants of BPJS Kesehatan Membership Using Generalized Ordered Logit- Unconstrained Partial Proportional Odds Model
}

\author{
Analisis Risiko Perubahan Kelas dan Determinan Kepesertaan BPJS Kesehatan dengan \\ Menggunakan Generalized Ordered Logit-Unconstrained Partial Proportional Odds \\ Model
}

\author{
Siskarossa Ika Oktora, ${ }^{1}$ Ika Yuni Wulansari, ${ }^{2}$ Geri Yesa Ermawan ${ }^{3}$ \\ 1,2,3 Politeknik Statistika STIS, JIn. Otto Iskandardinata No. 64C, Jakarta Timur, Indonesia, 13330 \\ Korespondensi: Siskarossa Ika Oktora \\ e-mail: siskarossa@stis.ac.id
}

\begin{abstract}
The main source of funding of BPJS Kesehatan comes from the different premium class in which the participant registered. The medical benefits among classes are equivalent, except inpatient facilities. But when the improvement health degree is not linear with the incurred costs, problem would arise. This study aims to analyze class shifting and determinants of BPJS Kesehatan membership. Around 1.53 percent of participants access higher classes, while 5.62 percent access lower classes. Class III participants with inpatient status severity level 2 and 3, reaching $41 \%$ and $43 \%$, respectively. In addition, $60 \%$ of non-PBI participants are Class II premium participants; most of them are male, productive age, and workers. This research using Generalized Ordered Log-itUnconstrained Partial Proportional Odds Model concludes that participants who are married tend to choose higher premium class. Whereas productive age participants and a worker is in the lower premium class. The recommendation is the evaluation of membership based on class premium contributions considering potential participants (productive age and workers) who tend should be conducted in a lower class. Although mutual assistance is the principle of National Health Insurance, specific mechanisms should be established to examine the relation of age and health status to each participant regarding the difference in the registered class, besides their economic factors.

Keywords: BPJS premium class, class shifting, Generalized Ordered Logit-Unconstrained Partial Proportional Odds Model
\end{abstract}

\begin{abstract}
Abstrak
Pendanaan utama BPJS Kesehatan adalah iuran peserta yang besarnya tergantung dari kelas premi yang didaftarkan peser- ta. Manfaatmedissetiap kelasadalahsetarakecualifasilitas ruanginap. Disisilain, halinidapatmenimbulkanpermasalahan ketika derajat kesehatan tidak linier dengan biaya yang seharusnya dikeluarkan. Penelitian ini bertujuan untuk melihat per- bedaan antara kelas premi saat peserta mengakses pelayanan kesehatan dengan kelas premi yang didaftarkan. Ditemukan 1,53 persen peserta mengakses kelas lebih tinggi dibanding kelasyang terdaftar, dan 5,62 persen pesertayang mengakses kelas lebihrendah dibanding kelasyang terdaftar. Berdasarkantingkatkeparahan saatmenjalanirawatinap, diketahuibahwa peserta kelas III dengan status rawat inap tingkat keparahan 3 (berat) dan 2 (sedang) masing-masing mencapai $41 \%$ dan $43 \%$. Selain itu hampir 60 persen peserta yang membayar iuran sesuai dengan ketentuan yang ditetapkan (non PBI) adalah peserta iuran premi Kelas II yang sebagian besar merupakan peserta laki-laki, berusia produktif, dan berstatus sebagai pekerja. Hasil analisis dengan metode Generalized Ordered LogitUnconstrained Partial Proportional Odds Model disimpulkan bahwa peserta berstatus kawin cenderung berada pada kelas premi yang lebih tinggi. Sedangkan peserta usia produktif serta peserta dengan status pekerja cenderung berada pada kelas premi yang lebih rendah. Rekomendasi yang diberikan adalah evaluasi kepesertaan berdasarkan iuran premi kelas dapat dilakukan kembali mengingat peserta potensial (usia produktif dan berstatus sebagai pekerja) cenderung berada pada kelas yang lebih rendah. Selain itu meskipun asas gotong royongmenjadiprinsippelaksanaan Program JKN, namun sebaiknya dapat dibuat mekanisme tertentu agar dapat dicermati terkait dengan faktor usia dan derajad kesehatan peserta terhadap perbedaan kelas premi pesertayang didaftarkan tanpa mengabaikan kemampuan ekonomi yang bersangkutan.

KataKunci: kelas premi BPJS, perubahan kelas, Generalized Ordered Logit-Unconstrained Partial Proportional Odds Model
\end{abstract}




\section{INTRODUCTION}

Health insurance is one of the government's priorities in realizing the mandate of Article 34, paragraph 3 of the 1945 Constitution, which requires the state to develop social security for all people. It aims to build the highest degree of public health. The need for health is a basic need that must be met. Expenditures for other basic needs such as clothing, food, and housing can be predicted in advance, but it is not the case with the cost of medical expenses. Anderson, Dobkin, and Gross (2012) stated that people who are not registered health insurance tend to consume more expensive health costs. Thus all levels of society must prepare budget for health as early as possible, not only for now but also for the future. One of them is the ownership of health insurance. The availability of health insurance and increasedcoverage can help improve the quality of life of people and stability in society (Fukawa, 2002).

Because of the welfare level is uneven, the role of the government in assuring the public health insurance is absolute fulfilled. A step to- ward universal health coverage has been mani- fested since the government released the Law No. 40 of 2004 on the National Social Security System and the operation of the Health Securi- ty Agency (BPJS) on January 1, 2014. Through the National Health Insurance Program-Indonesia Healthy Card ( JKN-KIS) held by BPJS Kesehatan, the government ensures the entire population is protected by comprehensive, fair, and equitable health insurance (BPJS, 2019).

BPJS Kesehatan as a public organization that organizes the Health Insurance program is currently facing financial problems related to the budget deficit due to an imbalance between income and expenditure. The main funding of BPJS Health is the participants' contributions, which are divided into three premium classes. Mean- while, based on Article 17, paragraph 4 of Law No. 40 of 2004, health insurance funding for the poor and those who cannot afford is borne by the government in which the management is carried out by BPJS. However, some literature studies conclude that the amount of participants' contribution/premium is not under the needs-based on actuarial calculations. The amounts of fees depend on the premium class in which the participants registered.

The difference between class I, II, and III participants only lies in non-medical benefits, such as inpatient service when BPJS Health participants are hospitalized. Meanwhile, for medical benefits, such as the quality/quantity of drugs, the num- ber of drugs, the quality of the services of doctors and medical personnel, the medical actions taken in handling BPJS Kesehatan participants' illnesses, as well as other medical benefits, are equivalent. On the other hand, it can cause problems when the health degree is not linear with the costs that should be incurred.

Andersen (1968) stated that the demand for medical services crucially depends on variables that predispose utilization such as age, gender, and household composition, variables that enable utilization such as income and education, and needs variables such as the health status indicators. There is evidence of a horizontal inequity based on individual Socioeconomic Status (SES), even in the case of hospital services (Van der Heyden et al., 2003). Income level is found to be the most powerful predictor of hospital utilization rates (Bill- ings et al., 1993). Those in the lowest income quintile who are older, in low health state, who suffer greater hospitalization risks, and who have a lower probability of insurance appear to consume the greatest share of public expenditures in hospi- tals (Schofield, 2000).

Evidence of horizontal inequity based on education, income, ethnicity, and employment sta- tus are also found for inpatient admissions in the UK (Gravelle et al., 2003). Males appear to have lower health care utilization rates than females (Schofield,1996; Windmeijer and Santos Silva, 1997; Cameron et al., 1998; Winkelmann, 2004). Age-demand for health care relationship appears to be a quadratic relationship (Windmeijer and Santos Silva, 1997; Pohlmeier and Ulrich,1995; Cameron et al., 1998; Deb, 2001; Winkelmann, 2004). Previous research suggested that being married is predictive of better health status. Verbrugge (1979) studied morbidity and disability rates of nonmarried, married, and formerly married people using age-adjusted data from federal health surveys in 1960 and 1970. In the noninstitutional population, divorced and separated people have the worst health status. Meanwhile, widowed people rank second, followed by single people; married people appear healthiest.

Based on the Ministry of Health (2011), it is known that most diseases suffered by the young age group (15-49 years) are extracorporeal dial- ysis, while for the older age groups ( $>50$ years) are hypertension. Both of these diseases certainly require significant medical costs and potential for long-term treatment. Thus it is necessary to study 
the class selection of BPJS participants and analyze the difference between premium classes when participants access health services and registered premium classes. In addition, this study also identifies the characteristics and determinants of BPJS participants in each premium class.

The results of this study are expected to give an input and recommendation to the evaluation of income obtained by BPJS from participation and the amount of overall health expenditure by looking at the phenomenon of increasing incidence of chronic diseases from year by year. In addition, consideration is also needed regarding the level of economic growth and the increase in the real income of the community in determining the number of membership fees (Nolan, 2006).

\section{METHODS}

This study uses BPJS Kesehatan sample data from 2015-2016 with BPJS membership classes (Class I, Class II, Class III) as response variables, and Class III is the reference category. In this study, to measure the potential of funding originating from BPJS membership, the participants who receive benefit assistance are not included in the observation unit. The predictor variables used in this study are gender (female $=0$, male $=1$ ), marital status (divorced $=0$, married $=1$, unmarried $=2$ ), age $(65+=0,17-64=1)$, and segmentation of participants (non-workers $=0$, wage earners $=1$, non-wage participants $=2$ ). The category cod- ed 0 is the reference category. Descriptive analysis is used to analyze the BPJS class shifting while identifying the characteristics and determinants of BPJS participants in each premium class, Generalized Ordered Logit Using Unconstrained Partial Proportional Odds Model is used.

Ordinal logistic regression is one of the regression analyses used to determine the relationship between the response variable and the independent variable when the response variable has an ordinal scale or multilevel category and has more than or equal to three categories. Several logit models can be used in logistic regression, especially if the response variable is ordinal, namely cumulative logits, adjacent-categories logits, and continuation-ratio logits (Agresti, 2010).

The general cumulative probability is obtained from the sum of categories probability if there is response variable $\mathrm{Y}$ with an ordinal scale that has $\mathrm{J}$ categories, and are the probability for each category of response variables, as follows:

$$
P(Y \leq j \mid x)=\pi_{1}(x)+\cdots+\pi_{j}(x)
$$

Based on equation (1), then cumulative logit function as follow: (Agresti, 2000):

$$
\begin{gathered}
\operatorname{logit}[P(Y \leq j \mid x)]=\ln \frac{P(Y \leq j \mid x)}{1-P(Y \leq j \mid x)} \\
=\ln \frac{\pi_{1}(x)+\cdots+\pi_{j}(x)}{\pi_{j+1}(x)+\cdots+\pi_{j}(x)} .
\end{gathered}
$$

Kleinbaum and Klein (2010) explained the cumulative logit model should be fulfilled the assumption of proportional odds or also known as parallel-lines. It is called proportional odds models. The proportional odds assumption is a very important assumption in the logistic regression model. In the proportional odds model, each cumulative logit has an equal coefficient (slope). However, it does not rule out the possibility that the proportional odds assumption not fulfilled.

One of the solutions to overcome the problem is to implement the partial proportional odds model or non-proportional odds model. The partial model is advantageous because more straightforward than the non-proportional odds model and more flexible when compared to the proportional odds model (Fullerton and $\mathrm{Xu}$, 2018).

According to William (2006), the partial proportional odds model is an ordinal logit mod el that has partially different $\beta$ values and partly the same for the category of response variables. The partial proportional odds for the cumulative odds model was first introduced by Peterson and Harrell (1990). Furthermore, this model is also developed by Cole and Ananth (2001). Meanwhile, Wiliams (2006), and Hauser and Andrew (2006) conducted various studies and explain the estimation stages for each cumulative model. Cumulative logit function of partial proportional odds model, as follows:

$$
\begin{aligned}
\operatorname{logit}[P(Y>j \mid x)]=\ln \left[\frac{P(Y>j \mid x)}{1-P(Y>j \mid x)}\right] \\
=\ln \left[\frac{\frac{\exp \left(\alpha_{j}+X_{i} \beta_{j}\right)}{1+\exp \left(\alpha_{j}+X_{i} \beta_{j}\right)}}{1-\frac{\exp \left(\alpha_{j}+X_{i} \beta_{j}\right)}{1+\exp \left(\alpha_{j}+X_{i} \beta_{j}\right)}}\right] \\
=\ln \left[\frac{\frac{\exp \left(\alpha_{j}+X_{i} \beta_{j}\right)}{1+\exp \left(\alpha_{j}+X_{i} \beta_{j}\right)}}{\frac{1}{1+\exp \left(\alpha_{j}+X_{i} \beta_{j}\right)}}\right]
\end{aligned}
$$




$$
\begin{gathered}
=\ln \left[\exp \left(\alpha_{j}+X_{i} \beta_{j}\right)\right] \\
\operatorname{logit}[P(Y>j \mid x)]=\alpha_{j}+\beta_{1} X_{1}+\cdots+\beta_{j} X_{j}
\end{gathered}
$$

Peterson and Harrell (1990) and Lall et al. (2002) presented the equivalent parameter- ization of the partial proportional odds model, which is called the unconstrained partial propor- tional odds model. According to Fullerton and $\mathrm{Xu}$ (2018), this model can be interpreted as a model where parameter coefficients can be made differently for each subset of variables. In this case, the logit model is a nonproportional probability model that is restricted because the coefficients for each independent variable vary between equations by common factors (assuming one dimension).

Under the Peterson-Harrell parameterization, each explanatory variable has one coefficient $\beta$ and $M-2$ coefficient $\gamma$, where $M$ is the number of categories in the response variable, and the coefficient $\gamma$ represents a deviation from proportionality. The unconstrained partial model is nested between the proportional odds and the non-proportional odds of the logit model. Assumption of the proportional odds is retained for one subset of independent variables, $\mathrm{x}$, and relaxed for an- other subset, $\omega$ :

$\ln \left[\frac{P(y=m \mid \boldsymbol{x}, \boldsymbol{\omega})}{P(y=m+1 \mid \boldsymbol{x}, \boldsymbol{\omega})}\right]=\tau_{m}-\boldsymbol{x} \boldsymbol{\beta}-\boldsymbol{\omega} \boldsymbol{\eta}_{m}$

$(1 \leq m \leq M)$

where is a vector of coefficients with the proportional odds constraint and is a vector of coefficients that freely vary across cutpoint equations. Furthermore, the probability form for each $m$ category is:

$P(y=m \mid \boldsymbol{x}, \boldsymbol{\omega})=\left\{\begin{array}{l}\frac{\exp \left[\sum_{r=m}^{M-1}\left(\tau_{r}-\boldsymbol{x} \boldsymbol{\beta}-\boldsymbol{\omega} \boldsymbol{\eta}_{r}\right)\right]}{1+\sum_{q=1}^{M-1}\left\{\exp \left[\sum_{r=q}^{M-1}\left(\tau_{r}-\boldsymbol{x} \boldsymbol{\beta}-\boldsymbol{\omega} \boldsymbol{\eta}_{r}\right)\right]\right\}} \\ \frac{1}{1+\sum_{q=1}^{M-1}\left\{\exp \left[\sum_{r=q}^{M-1}\left(\tau_{r}-\boldsymbol{x} \boldsymbol{\beta}-\boldsymbol{\omega} \boldsymbol{\eta}_{r}\right)\right]\right\}}\end{array}\right.$

$1 \leq m \leq M-1$

$m=M$

\section{RESULTS}

The result of this study shows that there is 1.53 percent of participants who access the higher class than the registered class, and there is 5.62 percent of participants who access the lower class than the registered class. Based on the severity when hospitalized, it is known that the class III participants who categorized as inpatient status of severity 3 (severe) reaching 41 percent, while inpatient status the severity of 2 (moderate) reach- ing 43 percent. Participants who access the higher class than registered class in the inpatient status of the moderate severity category reaching 1.31 per- cent. Whereas participants who access the higher class than registered class in the status of hospital- ization for severe severity category reaching 3.77 percent. In addition, based on the survey conducted by BPJS Kesehatan, it is concluded that almost 60 percent of BPJS participants who pay contributions in accordance with the stipulated provisions (not recipients of APBN and APBD assistance) are participants categorized as paying Class II premium contributions, most of them are male participants, has productive age, and wage-earning worker sta- tus.

One type of disease that affects many people in productive age is hypertension. Based on Riskesdas (2018), it is known that the prevalence of hypertension in the Indonesian population, reaching 34.1 percent. This condition is increasing from the 2013 Riskesdas survey (25.8 percent). A study on measuring the cost of illness of hypertension is conducted by Utari and Rochmah (2017). The respondents of this study are patients of hypertension in Kediri. The result of this study concludes that the costs incurred by a person with hypertension in Kediri, reaching $\mathrm{Rp}$ $6,220,470$ per year. In addition, the needs of these costs will continue to rise as people with hypertension experience has complications such as heart disease, stroke, and kidney failure.

\section{DISCUSSION}

The ordinal logistic regression required the parallel-lines test, in which the null hypothesis is the slope for the variables of each ordinal equation is equal. The result shows that the p-value of gen- der, marital status, and the segmentation variable of participants are smaller than, while the p-val- ue for the age variable is greater than . It can be concluded that only the age variable satisfies the parallel-lines assumption for each equation. Due to the differences in decisions regarding parallel-lines in ordinal logistic regression, this study using the Generalized Ordered Logit Using Unconstrained Partial Proportional Odds Model method. From the results of the analysis using the method, a statistical summary is obtained as follows: 
Table 1. Output Summary of Generalized Ordered Logit Using Unconstrained Partial Proportional Odds Model

\begin{tabular}{|c|c|c|c|c|}
\hline \multirow{2}{*}{ Variable } & \multicolumn{2}{|c|}{ Beta } & \multicolumn{2}{|c|}{ Gamma } \\
\hline & Coeffisien & Standard Error & Coeffisien & Standard Error \\
\hline Gender & $0,5378 * * *$ & 0,0081 & $-0,1916 * * *$ & 0,0132 \\
\hline Age & $0,3547 * * *$ & 0,0148 & & \\
\hline Married & $-0,1508 * * *$ & 0,0176 & $0,1786^{* * *}$ & 0,0219 \\
\hline Unmarried & $0,5497 * * *$ & 0,0191 & $-0,5524 * * *$ & 0,0285 \\
\hline Wage Earners & $0,9440 * * *$ & 0,0160 & $-6,9628 * * *$ & 0,4130 \\
\hline Non Wage Participants & $1,1686^{* * * *}$ & 0,0159 & $3,4490 * * *$ & 0,0626 \\
\hline Constant 1 & \multicolumn{4}{|l|}{$-0,7234$} \\
\hline Constant 2 & \multicolumn{4}{|l|}{$-5,2306$} \\
\hline
\end{tabular}

Based on Table 1, the coefficient of the first equation is identical to the beta coefficient. While Gamma coefficient shows the magnitude of the deviation of the second equation coefficient from the first equation. From the table, the age variable does not have a gamma coefficient; this is because only the age variable fulfills the parallel-lines assumption. Thus the regression coefficient for the age variables in the two equations is equal. The equations for both models follow:

Cumulative logit equation for Class I category

$$
\begin{aligned}
& \text { logit }[P(Y>1 \mid x)]=-0,7234+0,5378 \text { Gender }+0,3547 \text { Age }-0,1508 \text { Married } \\
& \quad+0,5497 \text { Unmarried }+0,9440 \text { Wage Earners }+1,1686 \text { Non Wage Participants }
\end{aligned}
$$

Cumulative logit equation for Class II category

$$
\begin{gathered}
\text { logit }[P(Y>2 \mid x)]=-5,2306+0,3462 \text { Gender }+0,3547 \text { Age }+0,0278 \text { Married } \\
-0,0027 \text { Unmarried }-6,0189 \text { Wage Earners }+4,6176 \text { Non Wage Participants }
\end{gathered}
$$

From the equation, it can be concluded that male participants are more likely to be in the lower premium class, which is class II or class III. And based on the data distribution, the percentage of the male is mostly in class II. It is in line with Schofield (1996); Windmeijer and Santos Silva (1997); Cameron et al. (1998); Winkelmann (2004) concluded that males appear to have a lower health care utilization rates than females.

For the age variable, the participants in productive age (17-64 years) are more likely to be in the lower premium class. This condition is also consistent with the data distribution where participants of productive age are more dominant in class II, while participants aged 65 years and over are more dominant in class I. Age influences BPJS participation and tuition class preference. This is in line with the research by Lestari and Djamaludin (2017), which stated that the older a person is, the higher the level of participation in BPJS. Banerjee (2015) analyzed out-of-pocket expenses for different health care services among American retirees and revealed that the difference in costs is observed among the non-elderly (age <65) as well, but for the elderly, the difference is significantly greater.

Furthermore, there are differences conditions of each class by marital status. In the class I equa- tion, it can be concluded that participants who are married tend to be in a higher class (class I or II), while unmarried participants tend to be in a lower class. Whereas in the class II equation, it can be concluded that participants who are married are more likely to be in the lower class (class II or III). As for the unmarried participants tend to be at a 
higher class. Based on the data distribution, it is known that the married and unmarried partici- pants are dominant in premium class II.

Banerjee (2016) found the healthcare costs among married medicare beneficiaries are approximately half of those not married. Verbrug- ge (1979) concluded that married people appear healthiest. Kong (2010) examined the demographic determinants of health care coverage within the United States with a focus on how gender and marital status influence the likelihood of having health insurance using US Census Bureau Current Population Survey that consists of a large sample of adults aged 30 to 65 . The principal finding is that married adults have a much higher probability of having insurance than single, divorced, and widowed adults. Pandey, K. et al. (2019) analyzed 13,942 respondents in the MCBS dataset, 12,929 have complete data, of whom $6473(50.3 \%)$ are married. Of these, $58 \%$ (vs. $36 \%$ of those currently-not-married) are male, $45 \%$ (vs. $47 \%$ ) are age $>75,24 \%$ (vs. $70 \%$ ) have a household income below $\$ 25,000,18 \%$ (vs. $14 \%$ ) have excellent selfreported general health, and 56\% (vs. 36\%) have private insurance. Compared to unmarried respondents, married respondents have a trend toward higher odds of having a recent outpatient visit, and lower odds in the year before having had an inpatient stay.

Based on the segmentation of the participants, it can be concluded that non-wage participants tend to be in the lower premium class, whereas wage earners tend to be in a higher class. If it is concluded based on the data distribution, the nonwage participants are more in class III, while the wage earners are more in class II. The ev-idence from Economou, et al. (2007) supports the existence of employment status-demand for health care relationships, although it varies with respect to the type of health care examined and the institutional and environmental settings of the countries. Macassa, et al. (2014) investigated differences in health-care use according to employment status at the pick of the recent economic recession in Gävleborg Country in 2010. Employment status is statistically significant associated with health-care use. In the bivariate analysis, people who are not employed have odds ratio of 1.62 for health care use as compared to their employed counterparts. It finds that at the pick of the most recent economic recession, people who are out of work using more often health services as compared with their employed counterparts. If non-wage participants tend to be in the lower premium class while they are used more often health services, then, in the end, it will be very burden- some BPJS and can result in losses if it is not offset by adjusting the premium tariff class.

Harmon and Nolan (2001), using the probit model, concluded that income, education level, age, sex, marital status, and ownership influence the choice of health insurance. From the results of the study, the majority of participants of productive age are in the premium class II. A study conducted by Fukawa (2002) stated that the pattern of disease development at this time has changed. If previously, Tuberculosis is the most common disease, but now geriatric diseases such as hypertension, cerebrovascular disease, heart disease, and malignant neoplasms are more prevalent. Thus it is also necessary to consider the estimated amount of health expenditure when the population at this productive age enters old age with the morbidity of these diseases.

\section{CONCLUSION AND RECOMMENDATION}

Based on the results of the study, it is expected that an evaluation of membership based on class premium contributions can be carried out considering productive age participants and wage-earning workers tend to prefer the lower classes, even though the monthly fees charged are still lower than private health insurance in general. The need for disseminating to the public about the importance of health investment for the future and strict pen- alty also needs to be done to minimize the num- ber of participants making arrears in payments. In addition, although the principle of cooperation is the principle of the National Health Insurance pro- gram implementation, specific mechanisms should be made so that it can be examined in relation to the age and health status of participants regarding the difference in the registered premium class of participants in addition to the economic factors of the participants concerned.

\section{ACKNOWLEDGMENT}

The authors would like to thank the BPJS Kesehatan Indonesia for providing data in this study, as well as the Health Financing Activity Project Funded by USAID through ThinkWell LLC for providing scientific grants so that this research can be presented at the 6th Annual InaHEA Conference on 58 November 2019 in Nusa Dua Bali. The authors also gratefully acknowledge the supports of the Politeknik Statistika STIS. 


\section{REFERENCES}

Agresti, A. 2000. Categorical data analysis $\left(2^{\text {nd }} e d\right)$. New York: John Wiley \& Sons.

Agresti, A. 2010. Analysis ofordinal categorical data $\left(2^{\text {nd }} e d\right)$. New York: John Wiley \& Sons.

Andersen RM. 1968. Behavioral model offamilies' use of health services. Research Series No 25, IL: Center for Health Administration Studies, University of Chicago.

Anderson, M., Dobkin, C., Gross, T. 2012. The effect of health insurance coverage on the use of medical services. American Economic Journal: Economic Policy, American Economic Association. 4(1): 1-27.

Banerjee S. 2015. Utilization patterns and out-ofpocket expenses for different health care services among american retirees. EBRI Issue Brief. 411:1-20.

Banerjee, S. 2016. Differences in Out-of-Pocket Health Care Expenses of Older Single and Couple Households. EBRI Notes. 37(1).

Billings, J., Zeitel, L., Lukomnik, J., Carey, T. S., Blank, A. E., Newman, L. 1993. Impact of socioeconomic status on hospital use in New York City. Health affairs. 12(1): 162-173.

BPJS. 2019. Available on https://bpjs kesehatan. go.id/bpjs/pages/detail/2013/4. [19 Oktober 2019].

Cameron, A. C., Trivedi, P. K., Milne, F., Piggott, J. 1988. A microeconometric model of the demand for health care and health insurance in Australia. The Review of economic studies. 55(1), 85-106.

Cole, S. R., Cande V. A. 2001. Regression models for unconstrained, partially or fully constrained continuation odds ratios. International Journal of Epidemiology. 30:1379-82.

Deb, P. 2001. A discrete random effects probit model with application to the demand for preventive care. Health Economics. 10(5): 371-383.

Economou, A., Nikolaou, A., \& Theodossiou, I. 2007. Socioeconomic Status and Health Care Utilization: A Study of the Effects of Low Income, Unemployment and Hours of Work on the Demand for Health Care in the E.U. (University of Aberdeen Business School Working Paper Series; Vol. 2007, No. 15). Centre for European Labour Market Research.
Fukawa, T., 2002. Public health insurance in Japan. Washington, DC: World Bank.

Fullerton, A. S., \& Xu, J. 2018. Constrained and unconstrained partial adjacent category logit mod-els for ordinal response variables. Sociological Methods \& Research, 47(2): 169-206.

Gravelle, H., Sutton, M., Morris, S., Windmeijer, F., Leyland, A., Dibben, C., Muirhead, M. 2003. Modelling supply and demand influences on the use of health care: implications for deriving a needs- based capitation formula. Health economics. 12(12): 985-1004.

Hauser, R. M., Andrew, M. 2006. Another look at the stratification of educational transitions: The logistic response model with partial proportionality constraints. Sociological Methodology. 36:126.

Harmon, C. and Nolan, B. 2001. Health insurance and health services utilisation in Ireland. Health

Economics 10(2): 135-145.

Kleinbaum, D. G., Klein, M. 2010. Logistic Regression A Self-Learning Text ( $3^{\text {rd }}$ ed). Springer: New York

Kong, J. S. 2010. The Effects of Marital Status \& Gender on Health Care Insurance Coverage in the United States. Honors Projects. Paper 111.

Lall, R., M. J. Campbell, S. J. Walters, K. Morgan, and MRC CFAS Co-operative Institute of Public Health. 2002. A review of ordinal regression models applied on health-related quality of life assessments. Statistical Methods in Medical Research. 11: 49-67.

Lestari, F. H., Djamaludin, M. D. 2017. Perception and motivation of national health insurance program participation in Bogor. Journal of Consumer Sciences. 2(1): 39-50.

Macassa, G., Hiswåls, A. S., Ahmadi, N., Alfredsson, J., Soares, J., Stankunas, M. 2014. Employment status and health care utilization in a context of economic recession: Results of a population based survey in East Central Sweden. Science Journal of Public Health. 2(6): 610-616.

Ministry of Health. 2011. Buletin Jendela Data dan Informasi Kesehatan. Jakarta: Kementerian Kesehatan RI.

Nolan, B. 2006. The interaction of public and pri-vate health insurance: Ireland as a case study. The 
Geneva Papers on Risk and Insurance-Issues and Practice. 31(4): 633-649

Pandey, K. R., Yang, F., Cagney, K. A., Smieliauskas, F., Meltzer, D. O., Ruhnke, G. W. 2019. The impact of marital status on health care utilization among Medicare beneficiaries. Medicine. 98(12), e14871.

Peterson, B., Harrell, Jr, F. E.1990. Partial proportional odds models for ordinal response variables. Applied Statistics. 39: 205-217.

Pohlmeier, W., Ulrich, V. 1995. An econometric model of the two-part decisionmaking process in the demand for health care. Journal of Human Resources. 30(2): 339-361.

Riset Kesehatan Dasar. 2013. Riset Kesehatan Dasar. Jakarta: Badan Penelitian dan Pengembangan Kesehatan.

Schofield, D. 1996. The impact of employment and hours of work on health status and health service use. National Centre for Social and Econom- ic Modelling, Discussion Paper No. 11, University of Canberra, Australia.

Schofield, D. 2000. Public hospital expenditure: how is it divided between lower, middle, and upper income groups? Australian Economic Review. 33(4): 303-316.

Van der Heyden, J. H. A., Demarest, S., Tafforeau, J., Van Oyen, H. 2003. Socio-economic differences in the utilisation of health services in Belgium. Health policy. 65(2): 153-165.

Verbrugge, L. M. 1979. Marital status and health. Journal of Marriage and the Family. pp: 267285.

Williams, R. 2006. Generalized ordered logit/partial proportional odds models for ordinal dependent variables. Stata Journal. 6(1): 58-82

Windmeijer, F. A., Santos Silva, J. M. 1997. Endogeneity in count data models: an application to demand for health care. Journal of applied econometrics. 12(3): 281-294.

Winkelmann, R. 2004. Health care reform and the number of doctor visits - an econometric analysis. Journal of Applied Econometrics. 19(4): 455-472. 